\title{
The influence of sociocultural and structural contexts in academic change and development in higher education
}

\author{
Claire Englund $^{1}$ (D) $\cdot$ Anders D. Olofsson ${ }^{2} \cdot$ Linda Price $^{3}$
}

Published online: 10 March 2018

(C) The Author(s) 2018

\begin{abstract}
Teaching quality improvements frequently focus upon the 'development' of individual academics in higher education. However, research also shows that the academics' context has considerable influence upon their practices. This study examines the working environments of teachers on an online pharmacy programme, investigating contextual conditions that facilitate or impede academic change and development. Interview data and institutional policy documents are examined within a Cultural-Historical Activity Theory framework. Distinct differences in the teachers' sociocultural context were identified as influencing change and development. Departmental teaching cultures and patterns of communication influenced practice both positively, by offering collegial support, and negatively by impeding change. The findings have significance for academic development strategies. They suggest that departmental-level support should include communicative pathways that promote reflection upon and development of conceptions of teaching and learning.
\end{abstract}

Keywords Academic development - Cultural-historical activity theory - Teaching cultures · Structural teaching context $\cdot$ Pharmacy programme

Claire Englund

claire.englund@umu.se

Anders D. Olofsson

anders.d.olofsson@umu.se

Linda Price

linda.price@beds.ac.uk

1 Centre for Educational Development, Umeå University, SE-90187 Umeå, Sweden

2 Department of Applied Educational Science, Umeå University, SE-90187 Umeå, Sweden

3 Centre for Learning Excellence, University of Bedfordshire, University Square, Luton, Bedfordshire LU1 3JU, UK 


\section{Introduction}

Academic development activities frequently focus upon the individual development of academics (Kirkwood and Price 2006). However, research also shows that the context within which academics work has considerable influence upon practice (Van Schalkwyk et al. 2015; Leibowitz et al. 2014).

Building on earlier research by the authors (Englund et al. 2016), the present study examines the working environments of higher education (HE) teachers on an online Master of Science in Pharmacy (MSc Pharm) programme. Specifically, it investigates the sociocultural and structural context within which the teachers act in an effort to understand previously identified differences in conceptions of teaching and learning. The contextual conditions examined include disciplinary and departmental cultures and institutional policy and strategy (Mathieson 2011; Zhu and Engels 2014; Fanghanel 2007). Interview data and contextual data concerning the HE educational setting spanning a 12-year period are analysed within a Cultural-Historical Activity Theory (CHAT) framework (Engeström 1987, 2001). This sociocultural framework is used to enable an examination of how teaching practice at the microlevel of the individual is influenced by the sociocultural context at the meso-level of the department and the structural context of the institution at macro-level. Specifically, we investigated the question:

How do sociocultural and structural contextual conditions impact on the way university teachers conceptualise and approach teaching and learning?

\section{The teaching and learning context in higher education}

Price, Kirkwood and Richardson (2016) emphasise that to gain a deeper understanding of the complexity of teaching in $\mathrm{HE}$ it is necessary to adopt a holistic approach, taking into consideration individual differences in teachers' conceptions of teaching and learning, the sociocultural and the structural context within which they work and the relationship between these conditions. A CHAT framework is therefore applied in the present study to investigate the activity systems within which the teachers operate and their interrelationships. This makes it possible to analyse the multiple relationships within the system and explore tensions and contradictions that may facilitate or impede academic change and development. CHAT offers a broad approach to analysing organisational and contextual issues and is increasingly being used in HE to consider the tensions and contradictions within given educational contexts (Kaatrakoski et al. 2016; Ellis et al. 2010).

\section{Teachers' academic context}

At micro-level, the authors previously found distinct differences in the degree to which conceptions of teaching and learning changed among teachers on the MSc Pharm in a 10year longitudinal study (Englund et al. 2016). Findings indicated that a number of sociocultural and structural contextual conditions were significant. One important conclusion was that a deeper understanding of contextual conditions, such as the influence of departmental teaching cultures and the organisational structures of the context of practice, is necessary. 
Teachers' conceptions of teaching and learning and how these influence approaches to teaching is a well-researched field (Prosser and Trigwell 2014; Kember and Kwan 2000). The significance of variation in conceptions is how they impact on student learning: studentcentred beliefs about teaching and subsequent approaches to teaching correspond to deeper approaches to learning by students (Trigwell et al. 1999). However, the question remains as to what shapes teachers' conceptions of teaching and learning and what conditions contribute to their change and development? As investigated in this study, one possible explanation may lie in the influence of the sociocultural and structural context and how they shape academics' teaching and learning beliefs and practices.

\section{The sociocultural context: disciplinary differences and academic cultures}

At meso-level, disciplinary differences and academic cultures are highly influential in academic practices (Fanghanel 2009; Becher 2001; Trowler et al. 2012). Epistemological differences are evident in varying academic cultures. They result in divergent disciplinary teaching and learning norms and practices, where different conceptions of teaching and learning become apparent (Becher 2001; Neumann et al. 2010; Lee 2007).

Nonetheless, teachers' practices are influenced not only by the epistemological assumptions of the discipline but also by individual departmental cultures and conventions (Trowler 2009, 2014; Roxå and Mårtensson 2015). For example, the extent to which a department is perceived to value good teaching is linked with academics' approaches to teaching (Prosser and Trigwell 1999). Although university teachers are members of several contexts of practice, the academic department is frequently the most significant (Knight and Trowler 2000). The culture of a particular community, such as a department or programme, is continually (re)-constructed and maintained as members act and interact, change and are changed by the community (Ancona et al. 2004; Lave and Wenger 1991). Communication and dialogue, where meaning is negotiated, are important components of cultural construction and the development and maintenance of communities (Mårtensson and Roxå 2016).

The culture and context of practice also influence the long-term impact of continuing professional development (CPD) programmes (Stes et al. 2007; Leibowitz 2015) where lack of consensus and collaboration with colleagues is experienced as a constraint. The impact of CPD is influenced by the teachers' working context and supportive networks (Smith 2012), the predominant teaching culture of the community to which they belong (Trowler and Cooper 2002), and leadership within the department (Thoonen et al. 2011).

\section{Structural conditions: institutional policy and ideology}

At macro-level, teachers operate within structural conditions that can include institutional policies, regulations, the requirements of external evaluation bodies and the external political environment (Henkel 2000; Deem and Lucas 2007). These structures determine the physical and organisational context and can constrain or enable the choices and opportunities available to individuals and communities within the organisation (Mathieson 2011; Kaatrakoski et al. 2016). Institutional policies, particularly regarding promotions, rewards and educational technology use, influence the sociocultural context, including the norms and ideologies operating at institutional and departmental levels (Leibowitz 2015; Barman et al. 2014). For example, in a research-focused university, promotion criteria may focus solely on evidence of research output, excluding teaching-related activities (Cruz 2014; Fitzpatrick and Moore 2013). 
The institution sets the structural context indicating what is valued through policy and strategy directives. These directives influence discourse and set the tone for teaching and research (Quinn 2012; Cretchley et al. 2013). Nonetheless, institutional policies are interpreted by the department (Lee 2007; Price et al. 2016) where it is the local community that develops day-to-day practices (Knight and Trowler 2001). Hence, it is important to understand how the departmental context interprets, enacts and influences academic practices in relation to teaching and learning.

There is a paucity of studies into departmental and institutional contexts and their effect upon teachers' conceptions of teaching (Saroyan and Trigwell 2015; Lee 2007). A deeper understanding of these issues has practical implications for academic development strategies. Using CHAT as a framework enables an examination of individual teachers' experiences as a lens through which to explore the influence of the sociocultural and structural contexts and how these conditions interrelate and change over time.

\section{Cultural-Historical Activity Theory}

Cultural-Historical Activity Theory (CHAT) has its origin in the sociocultural perspective on learning and development. It is a theoretical framework that can be used to analyse human interactions and relationships within particular social contexts. From a CHAT perspective, the context for understanding learning and development through human actions is the activity system. Put differently, and as described by Blackler (2009), '...rather than the socially mediated individual being taken as the basic unit of analysis, the historically located activity system should be the fundamental unit' (p. 29). The activity system can be conceptually depicted as a unit of activity with six interconnected components: subject, object, material or cognitive cultural tools, community, rules and division of labour (Engeström 1987). Engeström (2001) proposed that interaction between subject and object is mediated not only by cultural tools but also by the community in which the activity is taking place, the implicit and explicit rules that direct the activity, and the division of labour between actors in the community.

In this study, CHAT is used to understand the activity systems within which teachers work and how sociocultural conditions such as the departmental teaching community and structural conditions such as institutional policy influence teaching practice. The object of the activity system is the online MSc Pharm programme as illustrated by Fig. 1. The outcome is students' successful completion of the programme, i.e. qualification as pharmacists. Mediational tools used include educational technology, teaching strategies used to support the students' learning processes and language, i.e. communication and dialogue between and among students and teachers. The community consists of the teachers and their sociocultural context, which may be their disciplinary department, programme teaching team or research team. The division of labour is the roles occupied by the actors in the programme activity system, e.g. programme board, department head or teacher and the power relations between them. Finally, the rules are the explicit and implicit norms of the community, institutional and programme policy and regulations, professional ethics, and external quality evaluation policy.

An activity system is never in perfect equilibrium; the components of the system continuously interact with each other causing inner contradictions (Engeström 2001; Barab et al. 2002). These contradictions can be thought of as historically evolving tensions that can have a negative or a positive impact on the system. Contradictions are frequently grounded in problems that affect the subjects' practice negatively, e.g. between a lack of resources and the need to improve teaching quality. They can also occur between different activity systems within a network, for example in the case of the online MSc Pharm programme, this can 
Tools: educational

technology, teaching

strategies,

communication

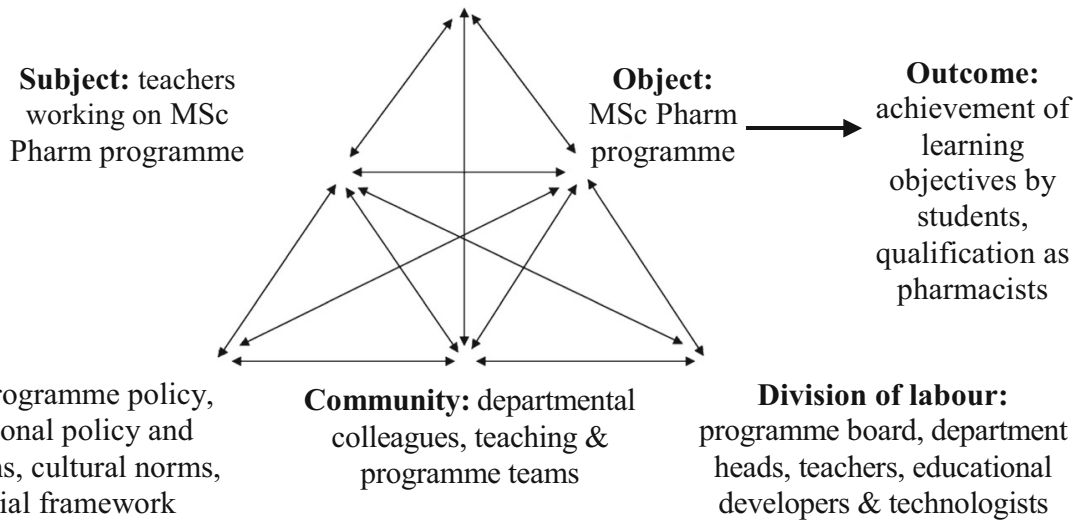

Rules: programme policy, institutional policy and regulations, cultural norms, financial framework
Community: departmental colleagues, teaching \&
Outcome: chievement of learning objectives by students, qualification as pharmacists

Fig. 1 The activity system of the online MSc Pharm programme, adapted from Engeström (2001)

involve tensions between the different systems to which teachers belong, such as the activity system of the department and that of the programme. Contradictions can however also have a positive effect, acting as driving forces for change within the activity by generating tensions that can lead to innovative attempts at development if participants have the opportunity to work collaboratively to solve them (Engeström 2001; Kerosuo et al. 2010).

By applying the CHAT framework in the case of the MSc Pharm programme, we were able to investigate the activity systems within which the teachers operate, exploring tensions and contradictions within and between systems, for example between the individual teachers (subjects), the sociocultural context (the community) and the structural context (rules). This made possible analysis of the multiple relationships within the system, both in the present and over time.

\section{Methods}

Data were collected from an online MSc Pharm programme at a Swedish university. In total, 47 semi-structured interviews were carried out with 24 teachers at five points over a 12-year period: 2004, 2008, 2011, 2014 and 2016. Data from eight teachers, who previously took part in a longitudinal study on changes in conceptions of teaching with educational technology, were complemented with interview data from an additional 16 teachers to provide more detail concerning departmental teaching contexts. A mixed methods approach was used (Creswell and Plano 2007) where interview data were combined with document analysis to provide contextual data concerning: departmental teaching culture, teachers' individual conceptions of teaching and learning, institutional policy and strategy and national quality evaluation policy. The research design and data sources are illustrated in Table 1.

The MSc Pharm programme is delivered almost entirely online using a variety of educational technology blended with two or three on-campus meetings per semester for laboratory work. Around 25 teachers are currently involved in the delivery of the programme although 
Table 1 Research design and data sources

\begin{tabular}{|c|c|c|c|}
\hline Method & Sampling regime & Rationale & Sample size \\
\hline $\begin{array}{l}\text { Interviews with } \\
\text { teachers from the } \\
\text { MSc Pharm } \\
\text { programme }\end{array}$ & $\begin{array}{l}\text { Purposive sampling. } \\
\text { Teachers from the three } \\
\text { departments contributing } \\
\text { to the programme }\end{array}$ & $\begin{array}{l}\text { Elicit a rich description of } \\
\text { sociocultural and } \\
\text { contextual conditions, e.g. } \\
\text { departmental teaching and } \\
\text { learning cultures and } \\
\text { perceived institutional and } \\
\text { departmental structural } \\
\text { context }\end{array}$ & $\begin{array}{l}\text { Dept } \mathrm{A}-9 \\
\text { Dept } \mathrm{B}-4 \\
\text { Dept } \mathrm{C}-11 \\
24 \text { teachers in total } \\
47 \text { interviews in total }\end{array}$ \\
\hline $\begin{array}{l}\text { Institutional } \\
\text { documentation } \\
\text { 2004-2016 with a } \\
\text { focus on vision and } \\
\text { strategy and } \\
\text { teaching and } \\
\text { learning } \\
\text { National quality } \\
\text { assurance policy }\end{array}$ & $\begin{array}{l}\text { Purposive sampling. } \\
\text { Documentation of overall } \\
\text { university strategy and } \\
\text { policy, teaching and } \\
\text { learning strategy, teaching } \\
\text { rewards system and } \\
\text { development project } \\
\text { funding }\end{array}$ & $\begin{array}{l}\text { Historical and current aspects } \\
\text { of contextual conditions at } \\
\text { institutional and national } \\
\text { level, e.g. overall strategy, } \\
\text { teaching and learning } \\
\text { strategy, teaching rewards } \\
\text { system, development } \\
\text { project funding and } \\
\text { national evaluation } \\
\text { framework }\end{array}$ & $\begin{array}{l}\text { Institutional policy and } \\
\text { strategy } \\
-8 \text { documents } \\
\text { Swedish national quality } \\
\text { evaluation policy } \\
-3 \text { documents } \\
11 \text { documents in total }\end{array}$ \\
\hline
\end{tabular}

the individuals have changed over time. The MSc Pharm is a joint programme where responsibility for delivery of modules on the programme is distributed between three departments: A, B and C. The departments are split between two faculties: the Faculty of Natural Sciences (A and B) and the Faculty of Medicine (C).

\section{Data analysis}

Interview data were transcribed verbatim and analysed using thematic analysis (Braun and Clarke 2006; Creswell and Plano 2007). The data were analysed focusing on sociocultural and structural contextual conditions experienced by respondents as contributing to or impeding academic change and development. The data were then re-examined and deductively coded with reference to the six components of CHAT: subject, object, tools, community, rules and division of labour. This was conducted for the activity systems of the three departments: A, B, and C. Contradictions within and between systems were identified and differences and similarities between departments established.

To provide contextual data concerning structural conditions that may have influenced teaching practice, institutional policy and strategy and national policy documents for the quality assurance of HE programmes were analysed. The documents were read iteratively by the researcher and thematically coded focusing on the contextual conditions identified by participants in interviews as influencing practice (Bowen 2009; Hodder 2000). To gain a deeper understanding of the influence of organisational policy, a framework suggested by Cooper, Fusarelli and Randall (2004) was adapted and applied in the analysis of policy documents. This framework includes identification of the normative dimension, including the goals and assumptions of policy and strategy, and the operative dimension, including the implementation and evaluation of policy and strategy. 


\section{Results and analysis}

\section{Departmental sociocultural context}

The sociocultural context of each department is described using vignettes to provide a rich description of the context as experienced by the teachers in the study. Vignettes are frequently used in research to collect data (Hughes and Huby 2002) but can, as in the present study, also be used to present research data collected through interviews (Ely et al. 1997). The vignettes presented are composite narratives depicting a mix of experiences merged into a single account (Spalding and Phillips 2007). The aim of the narratives is to reveal typical patterns found across participants within the departments and to identify contradictions experienced by participants. The vignettes were developed directly from interview transcripts and are thus an accurate account consisting of direct quotations from several participants. A further advantage of composite narratives is the achievement of anonymity, where exact reporting may make a specific participant identifiable.

\section{Department A}

Vignette: Research is valued higher in terms of qualifications and coffee room chat. When you get research funding it's celebrated, but when you are responsible for a course and get positive course evaluations nobody says a word. Everything is calculated in terms of how much research funding you have; those who teach don't get funding and don't count. Attitudes are perhaps changing but not practice; management and senior researchers all talk about how important teaching is but none of them do it. It's the tradition here that if you're good at research you "buy" yourself out of teaching. I think there are many good teachers in the department but we don't share our ideas and talk; we don't seem to have the words for it or the channels. The younger staff have started to discuss teaching in the department and have begun 'team teaching.' Otherwise there's incredibly few meetings to discuss teaching. In order to have a rewarding dialog [about teaching] which might lead to the development of new ideas, we need to show a certain amount of respect and humility towards each other and I'm sorry, but that's just not widespread in this department. Management has two new buzz words: "student active" and "effective". But this is something driven by the department's poor economy, not out of consideration for the students. There's no discussion of what constitutes good teaching; we are instructed to record our lectures to save time, not to improve student learning.

A common opinion consistently voiced by teachers from department A is that research has a higher status than teaching, which is expressed both in terms of departmental culture and career structure. The departmental emphasis on research echoes institutional ideology as evidenced in the analysis of policy documents, prioritising research over teaching. More recent institutional initiatives to promote teaching have had some effect on departmental attitudes but as yet not on practice. Nonetheless, there is indication of a gradual change in the teaching culture of the department towards increased collaboration among younger teachers, although some feel that an open climate for discussion and exchange of ideas is lacking.

The contradiction between teaching and research is exacerbated by a lack of opportunities for pedagogical discussions or reflection concerning teaching and learning within the department. 
The majority of teachers work individually with their course modules and any collaborative work undertaken in the department is focused on practical or administrative aspects of teaching.

\section{Department B}

Vignette: If I do my teaching well and get good course evaluations I will just get more teaching. If I do it badly then I will be released from teaching and can concentrate on my research. There is no one who cares about teaching here, it's just research. So I try to avoid teaching as much as possible, which means I have to be a poor teacher, and that is ridiculous. We need to take education seriously because it is so important, but at the same time, although you try to do your best as a teacher, it's research that's the main task. You do what you are obligated to do as well as possible. Support in terms of CPD is totally lacking from departmental management. You just get a message "the teaching committee have decided that you should do this teaching" - like it or not, it's just to do it. There is not much support, in fact there is no support. I feel very much alone in the department as a teacher, there is no discussion of teaching. If I want to develop my modules I do it in my own time with my own ideas. There are a group of employees who teach and then there is an elite group who do research. A bit like an A and B team, actually. Teachers in department B experience little incentive to focus on the promotion of student learning or the development of their teaching skills. Support from the departmental community and management is lacking and few members of this department have participated in CPD activities. Teaching is frequently carried out by younger members of staff without permanent positions, and despite an interest in teaching, the strong research focus of the department restricts their possibilities for change and development. As in department A, teachers work individually and rarely have contact with other teachers on the programme or within their department. The communities of departments A and B did not provide support; collaboration or opportunities for formal or informal discussion appear to be lacking. The departments' research focus also placed time constraints on the teachers through the rules governing allocation of teaching time. The priority awarded research echoes institutional policy and ideology and does not appear to facilitate a positive attitude to teaching or a desire to improve student learning.

\section{Summary of departments A and B}

The activity systems of the two departments are similar and are represented diagrammatically in Fig. 2 as a single system. Several contradictions within the activity systems of departments A and B can be identified, both within and between components and also in the participants' understanding of the object.

As illustrated by the vignettes, teachers in departments A and B frequently found it difficult to reconcile their desire to develop their teaching with the departments' objective to produce research, experiencing a contradiction between teaching and research. Teaching is awarded lower priority and there is little encouragement to participate in CPD.

The different conceptions of teaching and learning held by members of the department also resulted in different understandings of the object, teaching on the MSc Pharm. For a teacher with a student-centred teaching approach, supporting student learning is the object of the activity. However, with a teacher-centred approach, the teaching and delivery of content is the 
object. These contradictions are aggravated by the lack of communication within the system, hampering opportunities for dialogue and reflection as a mediating tool among members of the community.

The teachers participated simultaneously in several activity systems, for example the programme, the department and the institution. Contradictions frequently emerged between the object of the programme teaching activity system to support student learning and that of the department to produce research. Opportunities for negotiation and discussion of possible solutions to the contradictions between activity systems seem to be lacking in both departments.

\section{Department C}

The situation within department $\mathrm{C}$ differs from A and B in several respects. Department $\mathrm{C}$ has a close disciplinary relationship with the MSc Pharm programme and is also smaller and more financially dependent on the programme. Thus far, there has been little pressure to carry out research and the teachers have experienced fewer contradictions.

Vignette: Here at our department teaching probably has quite high status because there are more of us that are employed to teach. So, it's not research intensive really. I'm not sure if it's high status or not, it's just what we do. It's not written down, but the teaching philosophy of our department is that we are not there to teach the students, we are there to help students learn for themselves. It's reflected pretty much in the structures of our modules. I've had good support from colleagues here. If you need advice or have a problem or something you can always talk about it in the coffee room. When I worked at department A it was almost impossible to discuss teaching methods or even research; it's easier to discuss and exchange ideas with the others at $\mathrm{C}$; more open. We try to work together as a team. Working with the project around virtual reality [OpenSim] also contributed to a large part to my development as a teacher. We discuss our courses and teaching a lot here [at C]. So it's first and foremost here, with colleagues that are more experienced that I learn things. We discuss mostly practical questions, but we discuss

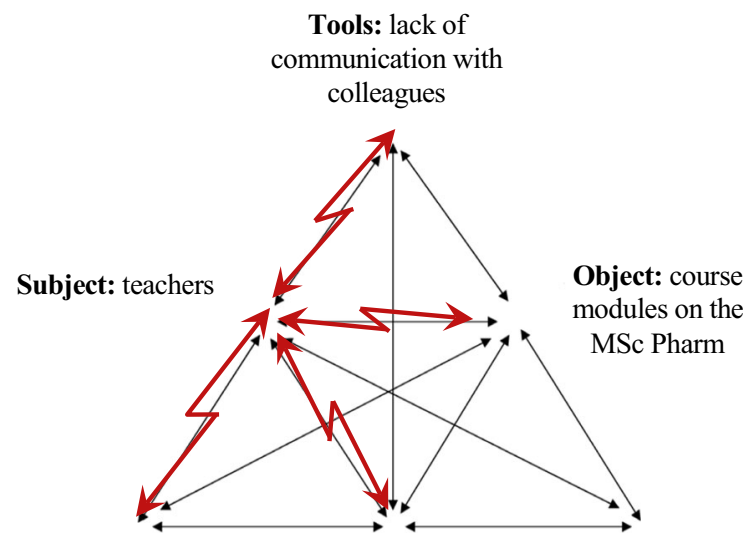

Rules: research prioritised, time constraints on teaching
Community: lack of collegial support
Division of labour: teachers work alone

Fig. 2 Contradictions in the activity systems of departments A and B 
pedagogy too. We talk a lot, but it's not organised like seminars or lectures, it's more an informal chat over coffee. The head of department has indicated very clearly that it would be good for the department if we could publish more but he is well aware of our time restraints. If we research who is going to teach? Our jobs are financed by undergraduate education so we'd have to find research funding elsewhere. He doesn't pressure us, but he doesn't provide any time either.

In contrast to departments $\mathrm{A}$ and $\mathrm{B}$, teachers in $\mathrm{C}$ have experienced good support from the community, where collaboration is common and teachers frequently assist in each other's courses. There are many opportunities to discuss teaching and learning, creating a climate of openness and trust. Two of the teachers have recently transferred from department A to C, and both expressed that the teaching culture and support offered by colleagues is very different in department $\mathrm{C}$. With regard to the teaching and learning culture of this department, a studentfocused, process-oriented teaching approach was expressed in interviews.

Teachers from department $\mathrm{C}$ are encouraged by colleagues and management to participate in CPD. Over the past six years, the community has actively encouraged members to apply for funding for developmental teaching projects and several applications from department $\mathrm{C}$ have been successful. The opportunity to test new ideas and technology in teaching and time for reflection have had positive impacts on their teaching.

Teachers in department $\mathrm{C}$ have as yet not experienced major contradictions within the activity system. However, potential contradictions are evident in interviews from 2016, indicating that the research focus of the department is increasing. However, teachers in department $\mathrm{C}$ are supported by a strong collaborative community and are able to seek solutions to contradictions through dialogue and communication within the community and with management.

\section{Summary of sociocultural context analysis}

Table 2 summarises the CHAT analysis of the three departments. There are clear differences between these departments in their objects, in the support provided by the community, and in the presence of communication channels enabling dialogue as a mediational tool. These systemic differences influence opportunities for individual teacher development and can act as a barrier or enabler of conceptual change.

CHAT analysis made visible relationships between the individual's activity, the systems of activity within which the individuals act and the conditions of influence within them. It afforded a deeper understanding of sociocultural contextual conditions and the identification of inherent systemic contradictions in the activity systems of the participants. Conditions identified by participants as contributing or inhibiting academic development included departmental teaching cultures, collegial support and institutional policy and strategy. The longitudinal nature of the study also allowed the identification of changes over time and an understanding of the historical roots of specific issues.

\section{Structural context}

Analysis of central documents concerning institutional and national policy and strategy facilitated an understanding of the structural context. As illustrated in Table 3, this made possible the identification of trends and changes in policy concerning teaching and research 
over time. From a CHAT perspective, policy and strategy form the rules governing activity and shape the framework within which teachers must act.

From a normative perspective, research was awarded clear priority in institutional strategy and vision documents 2003-2009; it is foremost in terms of positioning in documents and receives greater financial support. Education gained equal prominence in strategy documents 2009-2016. However, while goals for research are expressed in terms of becoming 'outstanding' and 'internationally renowned', education aims to be 'attractive' and 'internationally respected'. Operationally, activities to develop research were creative environments, top-class infrastructure and international communities, while developments in education are mainly concerned with the improvement of the pedagogical skills of teachers and retention of students.

Policy documents focusing on teaching and learning (2002-2013) included guidelines for development; however, the evaluation of implementation was lacking. It is not until the introduction of the Pedagogical Qualifications Model in 2013 (Umeå University 2013) that financial and career incentives for teachers and recognition of teaching excellence were offered by the institution. On a national level, Swedish quality assurance has moved from enhancement (2001-2010) to control of results (2011-2016), resulting in a focus on outcomes rather than the processes of teaching and learning.

In the analysis of institutional and national policy and strategy directives, it can be concluded that teaching and learning are not prioritised areas in HE. It is also notable that the student and student learning are almost invisible in both institutional and national policy. Goals are expressed in terms of increasing the institution's competitive edge rather than improving student learning. While there is an increasing intention to recognise the value of teaching by offering extrinsic forms of motivation such as pedagogical qualification, both institutional and national policy and strategy directives effectively undervalue teaching in comparison to research.

\section{Discussion and conclusions}

The aim of this study was to explore how cultural and structural contextual conditions impact on how HE teachers conceptualise and approach teaching and learning. The CHAT framework enabled the identification of sociocultural and structural contextual conditions and systemic

Table 2 CHAT comparison of departments

\begin{tabular}{|c|c|c|c|}
\hline CHAT concepts & Department A & Department B & Department $\mathrm{C}$ \\
\hline Subject & Teachers & Teachers & Teachers \\
\hline Object & $\begin{array}{l}\text { Modules on pharmacy } \\
\text { programme/research }\end{array}$ & $\begin{array}{l}\text { Modules on pharmacy } \\
\text { programme/research }\end{array}$ & $\begin{array}{l}\text { Modules on pharmacy } \\
\text { programme }\end{array}$ \\
\hline Tools & $\begin{array}{l}\text { Few channels for dialogue } \\
\text { and communication }\end{array}$ & $\begin{array}{l}\text { Few channels for dialogue } \\
\text { and communication }\end{array}$ & $\begin{array}{l}\text { Good communication and } \\
\text { dialogue }\end{array}$ \\
\hline Rules & Research prioritised & Research prioritised & Teaching prioritised \\
\hline Division of labour & $\begin{array}{l}\text { Individual teachers, gradual } \\
\text { movement towards } \\
\text { teamwork }\end{array}$ & Individual teachers & Teamwork \\
\hline Community & $\begin{array}{l}\text { Initially poor support by } \\
\text { community, gradual } \\
\text { improvement }\end{array}$ & No support by community & $\begin{array}{l}\text { Supportive, community based } \\
\text { on trust and collaboration }\end{array}$ \\
\hline
\end{tabular}




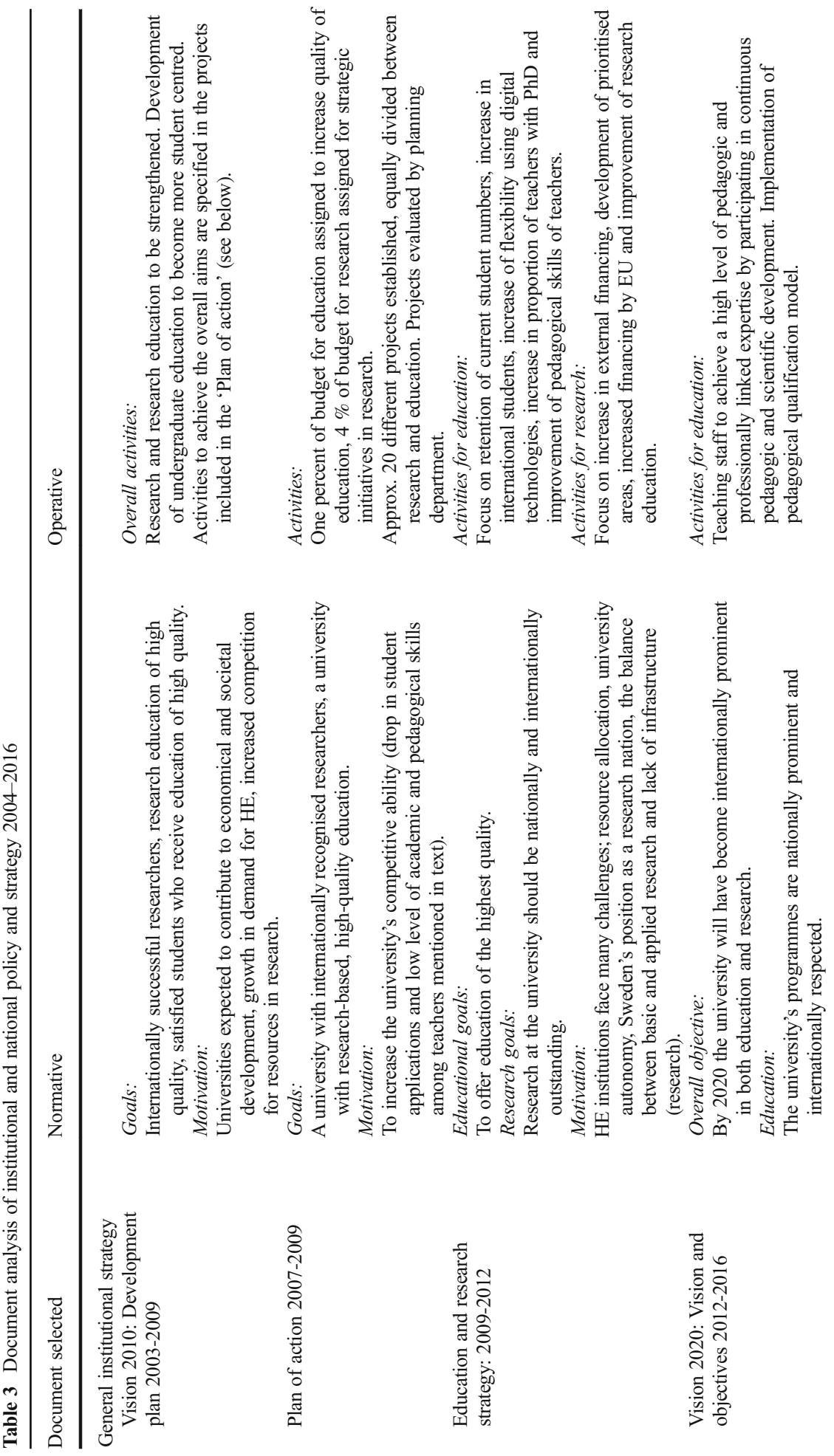




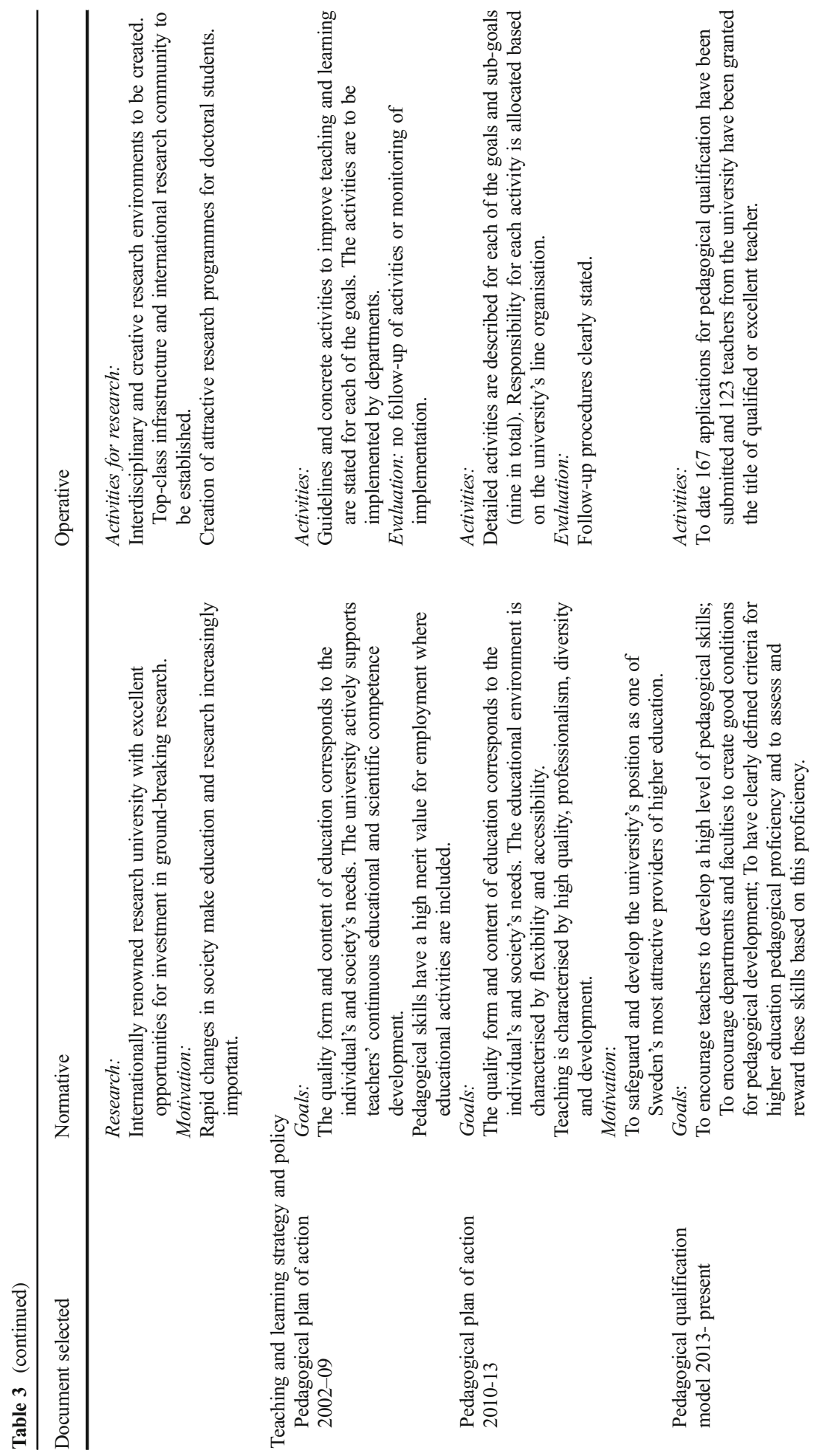




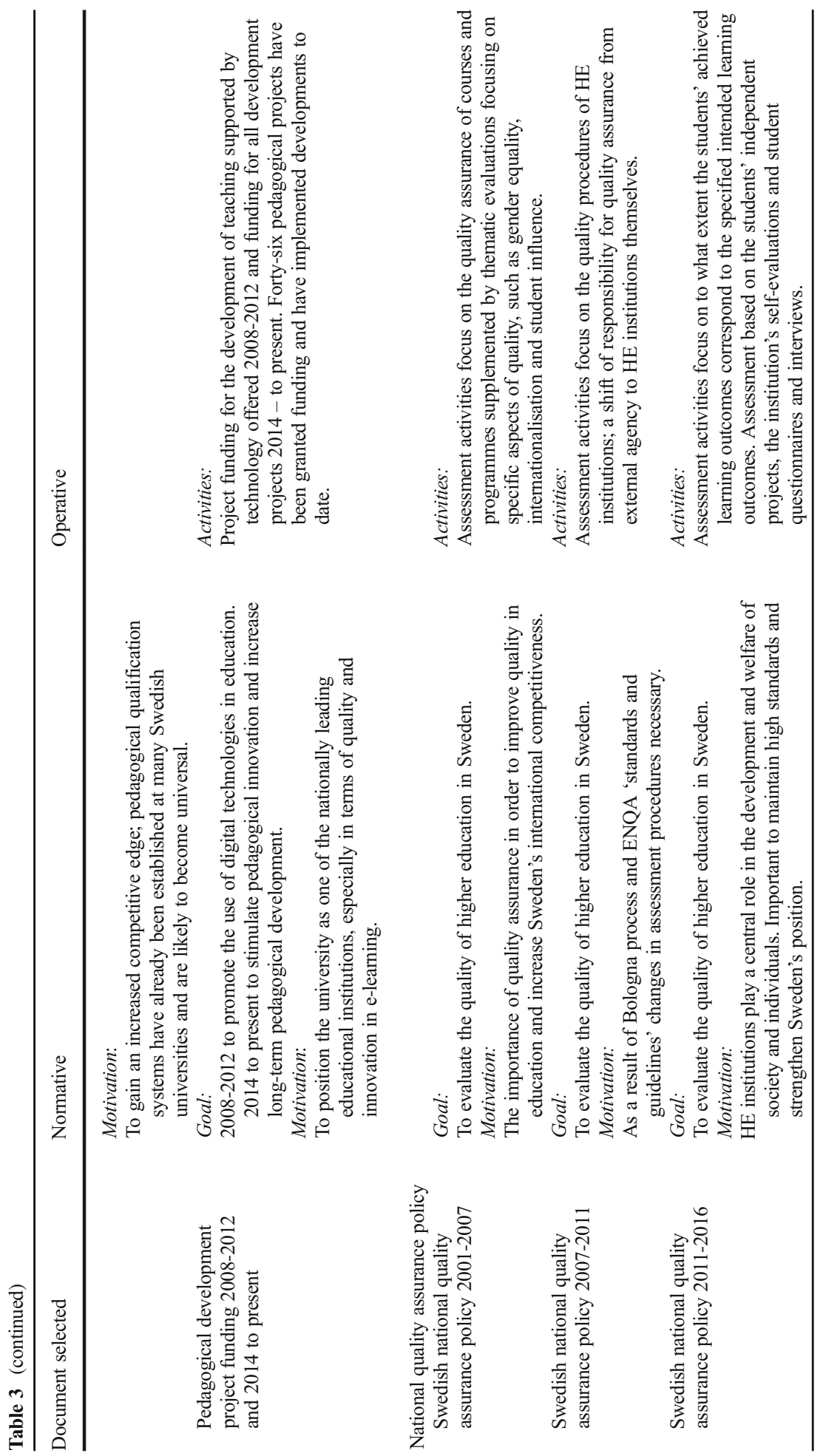


contradictions manifest within and between the activity systems of the teachers and departments.

\section{Sociocultural conditions}

CHAT analysis of the departmental activity systems enabled identification of contradictions within activities and the mediational tools available to participants when seeking solutions. Departmental communities influence teaching cultures and practice both positively and negatively; they can provide collegial support in development processes or act as a barrier to the implementation of new ideas. Distinct differences in the cultures and working practices of the departments were identified, which in turn influenced teachers' possibilities to develop and change.

In department $\mathrm{A}$, teachers worked in a loosely integrated fashion: discourse mainly concerned the practicalities of teaching. Conceptual discussions around teaching have gradually increased but there is little collaboration in practice. Similarly, in department B, communication concerning teaching was limited with few possibilities for discussion. In both departments A and B, there would seem to be limited avenues for pedagogic discussion as a mediational tool to solve tensions and contradictions. Consequently, when contradictions are manifested between the object of the teacher to support student learning and the object of the department to produce research, there are few opportunities for re-negotiation by the community. As discussed by Wertsch (2007), the intentional inclusion of opportunities for dialogue as a mediational tool can facilitate collaborative solutions to emergent contradictions.

The teaching culture in department $\mathrm{C}$ however provided a supportive community with many informal and formal possibilities for communication, which facilitated the development of conceptions of teaching and learning (2016). Department C is not however without disruptions in their activity system; challenges arise from outside their community. These challenges include increasing demands to teach more courses using less time and to produce more research. Nonetheless, an important characteristic of this community is their ability to communicate; there is a culture of collaborative problem solving. Members of department $\mathrm{C}$ share a common teaching and learning philosophy, have similar epistemic beliefs, and adopt a supportive team approach to teaching. These findings align with earlier research by Daniels (2011) where collaborative settings were associated with pedagogic discourse focusing on values and beliefs. Whereas, competitive cultures of individualism were associated with discourse in which transmission of skills and performance predominates.

\section{Structural conditions}

The departmental community plays an important role in the interpretation of institutional policy and ideology. It mediates policy translating it into practice 'filtered through local experience and histories' (Clegg and Bradley 2006). In departments A and B, the research focus of the institution, as effected by policy, was reflected in departmental culture, permeating the explicit and implicit rules governing the community. Teaching and CPD were not prioritised by management or the community. For department $\mathrm{C}$, however, the contradiction between the prevailing institutional ideology of teaching as secondary to research and the department's focus on teaching was mediated by the community. The institution sets the rules and these rules mediate between subject and community but as could be seen, communities interpret rules in different ways. 
From 2012, there has been increased effort by the institution to raise the status of teaching by rewarding excellence in teaching, by the inclusion of teaching as a criterion at employment and by funding teaching development projects. This has led to a gradual change in attitudes. Despite these efforts, the research-teaching nexus continues to be a challenge at both local and national levels (Price et al. 2016; Chalmers 2011). Its roots lie in the structural organisation and funding of the university and it is consequently notoriously difficult to amend (Kirkwood and Price 2016). Change is a complex, systemic process in which 'local' implementation must coincide with 'global' vision (Knight and Trowler 2001). Results indicate that the emphasis on research underlying institutional ideology and policy affects the local context of the teachers' departmental community. These findings confirm earlier research (Price et al. 2016; Lee 2007; Kaatrakoski et al. 2016) that the structural framework of the institution impinges on the teachers' possibilities for change and development.

\section{Conclusions}

While results are limited to this case study, it confirms other findings concerning the influence of context on practice and opportunities for development. CHAT analysis showed clear patterns of contradiction and interaction that influenced teaching practice. Communication and dialogue are important components of cultural construction and the development and maintenance of communities. It is therefore important to develop these pathways in order to facilitate conceptual change and strengthen teaching communities (Roxå and Mårtensson 2009; Mårtensson and Roxå 2016).

Previous research has emphasised the necessity of a holistic approach to understanding the inter-related conditions involved in the learning, teaching and technology nexus (Fanghanel 2004; Price et al. 2016). This has been confirmed in this study where sociocultural and structural contextual conditions were seen to impact on teaching practice and opportunities for change and development.

Open Access This article is distributed under the terms of the Creative Commons Attribution 4.0 International License (http://creativecommons.org/licenses/by/4.0/), which permits unrestricted use, distribution, and reproduction in any medium, provided you give appropriate credit to the original author(s) and the source, provide a link to the Creative Commons license, and indicate if changes were made.

\section{References}

Ancona, D., Kochan, T., Scully, M., Van Maanen, J., \& Westney, D. (2004). Managing for the future: organizational behavior and processes (3rd ed.). Boston, MA: SouthWestern College Publishing.

Barab, S. A., Barnett, M., Yamagata-Lynch, L., Squire, K., \& Keating, T. (2002). Using activity theory to understand the systemic tensions characterizing a technology-rich introductory astronomy course. Mind, Culture, and Activity, 9(2), 76-107. https://doi.org/10.1207/S15327884MCA0902_02.

Barman, L., Bolander-Laksov, K., \& Silén, C. (2014). Policy enacted-teachers' approaches to an outcomebased framework for course design. Teaching in Higher Education, 19(7), 735-746. https://doi.org/10.1080 /13562517.2014.934346.

Becher, T. (2001). Academic tribes and territories: intellectual enquiry and the culture of disciplines (2nd ed.). Philadelphia: SRHE \& Open University Press.

Blackler, F. (2009). Cultural-historical activity theory and organization studies. In A. Sannino, H. Daniels, \& K. D. Gutiérrez(Eds.), Learning and expanding with activity theory (pp. 19-39). New York: Cambridge University Press. 
Bowen, G. A. (2009). Document analysis as a qualitative research method. Qualitative Research Journal, 9(2), 27-40. https://doi.org/10.3316/QRJ0902027.

Braun, V., \& Clarke, V. (2006). Using thematic analysis in psychology. Qualitative Research in Psychology, 3(2), 77-101. https://doi.org/10.1191/1478088706qp063oa.

Chalmers, D. (2011). Progress and challenges to the recognition and reward of the Scholarship of Teaching in higher education. Higher Education Research \& Development, 30(1), 25-38. https://doi.org/10.1080 $/ 07294360.2011 .536970$.

Clegg, S., \& Bradley, S. (2006). The implementation of progress files in higher education: reflection as national policy. Higher Education, 51(4), 465-486. https://doi.org/10.1007/s10734-004-7764-8.

Cooper, B. S., Fusarelli, L. D., \& Randall, E. V. (2004). Better policies, better schools: theories and applications. Boston: Allyn \& Bacon.

Creswell, J. W., \& Plano, V. L. (2007). Designing and conducting mixed methods research. Ca. USA: Sage.

Cretchley, P. C., Edwards, S. L., O’Shea, P., Sheard, J., Hurst, J., \& Brookes, W. (2013). Research and/or learning and teaching: a study of Australian professors' priorities, beliefs and behaviours. Higher Education Research \& Development, 33(4), 649-669. https://doi.org/10.1080/07294360.2013.863836.

Cruz, L. (2014). Opposing forces: institutional theory and second-generation SoTL. International Journal for the Scholarship of Teaching and Learning, 8(1), 1. https://doi.org/10.20429/ijsotl.2014.080101.

Daniels, H. (2011). Analysing trajectories of professional learning in changing workplaces. Culture \& Psychology, 17(3), 359-377. https://doi.org/10.1177/1354067X11408137.

Deem, R., \& Lucas, L. (2007). Research and teaching cultures in two contrasting UK policy contexts: Academic life in Education Departments in five English and Scottish universities. Higher Education, 54(1), 115-133. https://doi.org/10.1007/s10734-006-9010-z.

Ellis, V., Edwards, A., \& Smagorinsky, P. (2010). Cultural-historical perspectives on teacher education and development: learning teaching: Routledge.

Ely, M., Vinz, R., Downing, M., \& Anzul, M. (1997). On writing qualitative research: living by words. London: Routledge Falmer.

Engeström, Y. (1987). Learning by expanding: an activity-theoretical approach to developmental research. Orienta-Konsultit Oy: Helsinki.

Engeström, Y. (2001). Expansive learning at work: toward an activity theoretical reconceptualization. Journal of Education and Work, 14(1), 133-156. https://doi.org/10.1080/13639080020028747.

Englund, C., Olofsson, A. D., \& Price, L. (2016). Teaching with technology in higher education: understanding conceptual change and development in practice. Higher Education Research \& Development, 36(1), 73-87. https://doi.org/10.1080/07294360.2016.1171300.

Fanghanel, J. (2004). Capturing dissonance in university teacher education environments. Studies in Higher Education, 29(5), 575-590. https://doi.org/10.1080/0307507042000261553.

Fanghanel, J. (2007). Local responses to institutional policy: a discursive approach to positioning. Studies in Higher Education, 32(2), 187-205. https://doi.org/10.1080/03075070701267244.

Fanghanel, J. (2009). The role of ideology in shaping academics' conceptions of their discipline. Teaching in Higher Education, 14(5), 565-577. https://doi.org/10.1080/13562510903186790.

Fitzpatrick, M., \& Moore, S. (2013). Exploring both positive and negative experiences associated with engaging in teaching awards in a higher education context. Innovations in Education and Teaching International, 52(6), 621-631. https://doi.org/10.1080/14703297.2013.866050.

Henkel, M. (2000). Academic identities and policy change in higher education (Vol. 46, Higher Education Policy Series). London: Jessica Kingsley Publishers Ltd..

Hodder, I. (2000). The interpretation of documents and material culture. In N. K. Denzin \& Y. S. Lincoln (Eds.), Handbook of qualitative research (2nd ed., pp. 703-715). Thousand Oaks, CA: Sage.

Hughes, R., \& Huby, M. (2002). The application of vignettes in social and nursing research. Journal of Advanced Nursing, 37(4), 382-386. https://doi.org/10.1046/j.1365-2648.2002.02100.x.

Kaatrakoski, H., Littlejohn, A., \& Hood, N. (2016). Learning challenges in higher education: an analysis of contradictions within Open Educational Practice. Higher Education, 74(4), 599-615. https://doi.org/10.1007 /s10734-016-0067-z.

Kember, D., \& Kwan, K.-P. (2000). Lecturers' approaches to teaching and their relationship to conceptions of good teaching. Instructional Science, 28(5), 469-490. https://doi.org/10.1023/a:1026569608656.

Kerosuo, H., Kajamaa, A., \& Engeström, Y. (2010). Promoting innovation and learning through change laboratory: an example from Finnish health care. Central European Journal of Public Policy, 4(1), 110-131.

Kirkwood, A., \& Price, L. (2006). Adaptation for a changing environment: developing learning and teaching with information and communication technologies. The International Review of Research in Open and Distance Learning, 7(2).

Kirkwood, A., \& Price, L. (2016). Technology-enabled learning implementation handbook. Commonwealth of Learning (COL). 
Knight, P., \& Trowler, P. (2000). Department-level cultures and the improvement of learning and teaching. Studies in Higher Education, 25(1), 69-83. https://doi.org/10.1080/030750700116028.

Knight, P., \& Trowler, P. (2001). Departmental leadership in higher education. U.K.: McGraw-Hill Education.

Lave, J., \& Wenger, E. (1991). Situated learning: legitimate peripheral participation. Cambridge: Cambridge Univ. Press.

Lee, J. J. (2007). The shaping of the departmental culture: measuring the relative influences of the institution and discipline. Journal of Higher Education Policy and Management, 29(1), 41-55. https://doi.org/10.1080 /13600800601175771.

Leibowitz, B. (2015). The professional development of academics as teachers. In J. M. Case, \& J. Huisman (Eds.), Researching higher education: international perspectives on theory, policy and practice (pp. 153165): Routledge.

Leibowitz, B., Bozalek, V., van Schalkwyk, S., \& Winberg, C. (2014). Institutional context matters: the professional development of academics as teachers in South African higher education. Higher Education, 69(2), 315-330. https://doi.org/10.1007/s10734-014-9777-2.

Mathieson, S. (2011). Disciplinary cultures of teaching and learning as socially situated practice: rethinking the space between social constructivism and epistemological essentialism from the South African experience. Higher Education, 63(5), 549-564. https://doi.org/10.1007/s10734-011-9458-3.

Mårtensson, K., \& Roxå, T. (2016). Working with networks, microcultures and communities. In D. Baume \& C. Popovic (Eds.), Advancing practice in academic development (pp. 174-187). London: New York: Routledge.

Neumann, R., Parry, S., \& Becher, T. (2010). Teaching and learning in their disciplinary contexts: a conceptual analysis. Studies in Higher Education, 27(4), 405-417. https://doi.org/10.1080/0307507022000011525.

Price, L., Kirkwood, A., \& Richardson, J. T. (2016). Mind the gap: the chasm between research and practice in teaching and learning with technology. In J. Case \& J. Huisman (Eds.), Researching higher education: international perspectives on theory, policy and practice (pp. 227-245). London: Routledge.

Prosser, M., \& Trigwell, K. (1999). Relational perspectives on higher education teaching and learning in the sciences. Studies in Science Education, 33(1), 31-60. https://doi.org/10.1080/03057269908560135.

Prosser, M., \& Trigwell, K. (2014). Qualitative variation in approaches to university teaching and learning in large first-year classes. Higher Education, 67(6), 783-795. https://doi.org/10.1007/s10734-013-9690-0.

Quinn, L. (2012). Understanding resistance: an analysis of discourses in academic staff development. Studies in Higher Education, 37(1), 69-83. https://doi.org/10.1080/03075079.2010.497837.

Roxå, T., \& Mårtensson, K. (2009). Significant conversations and significant networks - exploring the backstage of the teaching arena. Studies in Higher Education, 34(5), 547-559. https://doi.org/10.1080 $/ 03075070802597200$.

Roxå, T., \& Mårtensson, K. (2015). Microcultures and informal learning: a heuristic guiding analysis of conditions for informal learning in local higher education workplaces. International Journal for Academic Development, 20(2), 193-205. https://doi.org/10.1080/1360144x.2015.1029929.

Saroyan, A., \& Trigwell, K. (2015). Higher education teachers' professional learning: process and outcome. Studies in Educational Evaluation, 46, 92-101. https://doi.org/10.1016/j.stueduc.2015.03.008.

Smith, K. (2012). Lessons learnt from literature on the diffusion of innovative learning and teaching practices in higher education. Innovations in Education and Teaching International, 49(2), 173-182. https://doi. org/10.1080/14703297.2012.677599.

Spalding, N. J., \& Phillips, T. (2007). Exploring the use of vignettes: from validity to trustworthiness. Qualitative Health Research, 17(7), 954-962. https://doi.org/10.1177/1049732307306187.

Stes, A., Clement, M., \& Van Petegem, P. (2007). The effectiveness of a faculty training programme: long-term and institutional impact. International Journal for Academic Development, 12(2), 99-109. https://oi. org/10.1080/13601440701604898.

Thoonen, E. E. J., Sleegers, P. J. C., Oort, F. J., Peetsma, T. T. D., \& Geijsel, F. P. (2011). How to improve teaching practices: the role of teacher motivation, organizational factors, and leadership practices. Educational Administration Quarterly, 47(3), 496-536. https://doi.org/10.1177/0013161x11400185.

Trigwell, K., Prosser, M., \& Waterhouse, F. (1999). Relations between teachers' approaches to teaching and students' approaches to learning. Higher Education, 37(1), 57-70. https://doi.org/10.1023 /a:1003548313194.

Trowler, P. (2009). Beyond epistemological essentialism. In C. Kreber (Ed.), The university and its disciplines: teaching and learning within and beyond disciplinary boundaries (pp. 181-195). New York: Routledge.

Trowler, P. (2014). Depicting and researching disciplines: strong and moderate essentialist approaches. Studies in Higher Education, 39(10), 1720-1731. https://doi.org/10.1080/03075079.2013.801431.

Trowler, P., \& Cooper, A. (2002). Teaching and learning regimes: implicit theories and recurrent practices in the enhancement of teaching and learning through educational development programmes. Higher Education Research and Development, 21(3), 221-240.

Trowler, P., Saunders, M., \& Bamber, V. (2012). Tribes and territories in the 21st century: Routledge London. 
Umeå University (2013). Pedagogical Qualification Model. https://www.aurora.umu.se/en/employment/skillsdevelopment/pedagogical-qualification/ Accessed December 152016.

Van Schalkwyk, S., Leibowitz, B., Herman, N., \& Farmer, J. (2015). Reflections on professional learning: choices, context and culture. Studies in Educational Evaluation, 46, 4-10.

Wertsch, J. (2007). Mediation. In H. Daniels, M. Cole, \& J. Wertsch (Eds.), The Cambridge companion to Vygotskij (pp. 178-192). Cambridge: Cambridge University Press.

Zhu, C., \& Engels, N. (2014). Organizational culture and instructional innovations in higher education. Educational Management Administration \& Leadership, 42(1), 136-158. https://doi.org/10.1177 /1741143213499253. 